\title{
Evidence of Underpricing of Initial Public Offerings in Vietnam
}

\author{
TRÀ̀ THỊ HẢI LÝ \\ University of Economics HCMC \\ Email: haily@ueh.edu.vn \\ DU'ONG KHA \\ University of Economics HCMC \\ Email: khatcdn@ueh.edu.vn
}

\section{ARTICLE INFO}

Received:

March 21, 2013

Received in revised form

March 28, 2013

Accepted:

June 15, 2013

Keywords:

stock market

short-term underpricing

IPO

\begin{abstract}
This study was conducted to find evidence of short-term underpricing of initial public offerings (IPOs) and factors that explain the level of underpricing based on IPO samples in the period between January 2005 and July 2012 in Vietnam. The authors found certain evidence to support the underpricing, with the underpricing rate set at $38 \%$ and $49 \%$. Having bootstrapping regression model employed, the results showed that the two factors - the exceeding purchase ratio and the starting price of the auctions - negatively correlated as expected with underpricing rate while impact of market conditions appeared relatively weak. Other factors such as size, listing lateness, company age, state ownership after IPOs did not correlate with the underpricing levels in Vietnam.
\end{abstract}




\section{INTRODUCTION}

An Initial Public Offering (IPO) refers to the first sale of stock of a private company to the public. An IPO is an event that not only offers important implications for businesses but also is academically attractive via several empirical patterns commonly found in many international stock markets. One of those patterns is the underpricing.

IPOs carried out by Vietnamese firms have their own specific features. First, major IPOs are often conducted by the formerly state-owned enterprises and therefore after the IPOs, the state still holds large percentages of shares.

Next, the IPO pricing mechanism in Vietnam is based on separate auction, whereas the pricing mechanism in most markets is book building. In addition, the time interval for companies to list IPOs on official exchanges is quite long.

These traits require that research be carried out on the underpricing of IPOs right at this point and identify factors that govern the underpricing in order to provide strategic implications for investment in IPOs.

According to the authors' research, only the study of Ayayi (2011) has been conducted on Vietnamese market until now. However, this study has its own limitations: (1) it only examines IPOs from February 2005 to June 2007 - a period of bull market; therefore, extending the scope of study to include bear market is of necessity; (2) it does not apply any statistical test but an analysis of descriptive statistics and thus it could not reach a clear conclusion about evidence of underpricing; (3) it fails to test factors that affect the underpricing IPOs in Vietnam, and (4) it fails to consider underpricing in a larger sample including non-IPO auctions.

In fact, the statistical analysis of underpricing by Ayayi (2011) is only based on a sample size of 30 companies. This fact implies that further quantitative researches on Vietnamese IPOs are much needed.

\section{THEORETICAL BASIS}

\section{a. An Overview of IPOs:}

An IPO is a type of public offering where shares of stock in a company are sold to the general public for the first time. A company, in its life cycle, can carry out only one IPO. Part of an IPO may be the first issue (the company sells shares to raise expansion capital), or the second issue in which holders of shares before IPO (they usually are founders of the company or venture capital funds who have invested in the company since its beginning) transfer parts of their shares to new investors through an IPO. Three main entities taking part 
in an IPO are the issuer, underwriters and investors. Ownership structure and management mechanism of the company usually change substantially after an IPO.

Several pricing methods may be used, such as auctioning, selling at a fixed price, or book building. In auctioned IPOs, the price is determined by bids from investors during the auction. In fixed price method, the offering price is preset. If demand exceeds supply, allocation of shares will be based on number of shares demanded by investors. Underwriters will conduct road shows to introduce the IPO to potential investors thereby gauging the aggregate demand and acceptable price of shares. The issuing company and underwriters will meet to set the offering price and the number of shares to be issued at the IPO.

- Short-term underpricing:

Shares in IPOs are generally underpriced. It is neccesary, however, to understand this phenomenon from both theoretical and empirical aspects. Theoretically, underpricing a share means that its market price is lower than its intrinsic value, that is, difference between intrinsic value and issuing price is greater than zero. Accordingly, calculation of the intrinsic value is based on estimates of all future cash flows discounted to the present values. However, estimates of future cash flows of companies and discount rate are not easy tasks because of uncertainty of future cash flows. Empirically, an IPO share is considered underpriced when its market-adjusted rate of return in the first trading day is positive in which the market-adjusted rate of return is determined by difference between rate of return of IPO share and rate of return of market representative index on that first trading day.

Underpricing entails a huge cost for issuers and accounts for a large percentage of IPOrelated expenses. This cost, however, is accompanied by certain benefits for issuers that may help enhance possibility of success for the issue and save the company from missing business opportunities. Moreover, a low issuing price may increase the price shares when they are traded on the secondary market, thereby improving ability to raise new capital in the next issues.

- Factors explaining the underpricing:

From previous researches, the author can draw factors that explain the underpricing of IPOs:

+ Oversubscription: According to Biais \& Faugeron-Crouzet (2000), underpricing level decreases when the number of shares demanded increases implying that keener competition among investors makes IPO pricing more accurate and reduces underpricing degree. In the case of Chinese IPOs, Chi \& Padgett (2005) find that underpricing is mostly explained by 
imbalance between supply and demand, and a large percentage of buyers of IPO shares are individual investors who lack market information.

+ State ownership: Empirical researches on Chinese IPOs - an IPO market that has the state ownership similar to the Vietnamese one - find that the state ownership could explain the underpricing of IPOs. In an IPO conducted by a state-owned company, the state acts as the seller (owner of the company before IPO and co-owner after IPO), and buyers comprise outside investors who usually lack full information about quality of state-owned companies. To ensure success for IPOs, the state tends to underprice the shares to attract investors. Chi \& Padgett (2005) support this argument with findings from Chinese IPO market and conclude that degree of state ownership has a negative relationship with the underpricing.

+ Initial price: Initial issuing price of an IPO may reveal existence of underpricing. Setting a low issuing price usually aims at attracting potential investors. Ibbotson et al. (1988) find that companies that offer low issuing prices always accept high degrees of underpricing.

+ Size: Size of company is considered one of the measures of information asymmetry based on the argument that information about big companies is usually widely known and uncertainty about their future is lower than that of small enterprises. Adjasi et al. (2011) find evidence of a negative relationship between company size and underpricing.

+ Company age: Another measure of information asymmetry is the age of a company. Investors usually have more information about long-standing companies than about younger ones. Tian (2011) finds a negative relationship between the age of a company and underpricing degree among Chinese IPOs.

+ Listing time lag: The interval of time between IPO and share listing is another indicator of uncertainty and liquidity risk for both issuers and buyers. Longer time lag leads to higher degrees of risk and greater underpricing.

+ Corporate risk: Degree of underpricing will increase with uncertainty after issuance. Bradley et al. (2009) argue that corporate risk is directly proportional to underpricing.

+ Market conditions: Market condition is expected to have a positive relationship with rate of return on the first day of issue because demand for the IPO shares may increase in the first day if a bull market exists, which thereby makes the rate of return rise in the first day and vice versa.

\section{FOREIGN EMPIRICAL RESEARCHES}

American IPO market is the world's most dynamic even if the average underpricing ranges from $10 \%$ to $20 \%$. The systematic research by Ritter \& Welch (2002) shows that 
underpricing is found in American IPOs over time and average rate of return on the first issue day is $18.8 \%$.

Researches based on data from other developed markets also produce evidence of underpricing of IPOs. Chambers \& Dimson (2009) report that the average rate of return on the first issue day in the U.K. in the 1917-2007 period is $14.57 \%$. In Kerins et al. (2007) the underpricing of Japanese IPOs is $8.59 \%$.

In emerging markets degrees of underpricing are reportedly higher in comparison with developed ones. Tian (2011) finds that the average underpricing in Chinese market is $247 \%$. Adjasi et al. (2011) show that the average abnormal rate of return on the first issue days of 55 IPOs in Nigerian market is 43.28\%. Samarakoon (2010) provides evidence that underpricing of 105 IPOs in Sri Lankan stock exchange is 34\%. Boudriga et al. (2009) find that market-adjusted rate of return on the first trading days of 34 IPOs on Tunisian stock market is $16.07 \%$.

Thus, underpricing of IPOs is popular in most markets but it differs considerably among markets. Causes of this phenomenon may come from characteristics of an individual market, such as auctioning mechanism, duration of listing time, and types of ownership, etc.

\section{METHODOLOGY AND DATA}

\section{a. Measuring Underpricing of IPOs:}

The underpricing is mainly measured by market-adjusted rate of return on the first trading day. In developed markets, the interval between an IPO and listing time is usually short; and abnormal return (AR), if the share $\mathrm{i}$ is based on adjusted initial return on the first trading day, is as follows:

$$
A R_{i}=R_{i}-R_{m}
$$

where $R_{i}$ and $R_{m}$ are rates of return of the share $i$ and of the market from the IPO day to the first trading day of the share $i$, respectively.

Several researchers argue that evidence of underpricing may be sensitive to measuring methods. In underdeveloped markets in particular, the interval between IPO and listing time may last several months, or even years, which requires another formula for calculating the market-adjusted abnormal return (MAAR) as follows:

$$
M A A R_{i}=\frac{1+R_{i}}{1+R_{m}}-1
$$

This research employs both aforementioned scales to find a more exact conclusion about evidence of underpricing in Vietnam. 


\section{b. Testing Methods:}

T-test is used for determining whether unerpricing of IPOs exists or not.

Regression is used to estimate factors that explain the underpricing. Linear regression model is established with first day market-adjusted returns and independent variables presented in Table 1:

Table 1: Factors Explaining the Underpricing

\begin{tabular}{|c|c|c|}
\hline $\begin{array}{l}\text { Explanatory } \\
\text { variables }\end{array}$ & Sign & Explanation \\
\hline Oversubs & Demand & Shares ordered exceeds shares offered \\
\hline Listing time lag & LnDel & Logarithm of days from IPO to listing \\
\hline Company age & LnAge & $\begin{array}{l}\text { Logarithm of operating years from establishment } \\
\text { of company to IPO year }\end{array}$ \\
\hline Corporate risk & Std & $\begin{array}{l}\text { Standard deviation of returns from shares in six } \\
\text { months after the first trading day }\end{array}$ \\
\hline Size & LnFSize & Logarithm of total asset before IPO year \\
\hline $\begin{array}{l}\text { State ownership after } \\
\text { IPO }\end{array}$ & Stateown & Proportion of state ownership after IPO \\
\hline Market conditions & MarReturn & $\begin{array}{l}\text { Cumulative return of VNIndex in a } 3 \text {-month } \\
\text { period before the first trading day }\end{array}$ \\
\hline Initial price & LnResprice & Logarithm of initial price \\
\hline \multicolumn{3}{|c|}{$\operatorname{MAAR}($ or AR $)=\beta_{1}+\beta_{2}$ Demand $+\beta_{3}$ LnDel $+\beta_{4}$ LnAge $+\beta_{5} \mathrm{Std}+\beta_{6}$ LnFSize $+\beta_{7}$} \\
\hline \multicolumn{3}{|c|}{ Stateown $+\beta_{8}$ MarReturn $+\beta_{9}$ LnResprice $+\mathrm{e}_{\mathrm{t}}$} \\
\hline \multicolumn{3}{|c|}{ OLS regression, OLS robust to adjust errors, and bootstrapping process are performed. . } \\
\hline \multicolumn{3}{|c|}{$\begin{array}{l}\text { Although OLS regression is applied to most researches on explanatory factors of } \\
\text { underpricing of IPO in the world, bootstrap may lead to more reliable regression deductions } \\
\text { when the sample is small. Moreover, bootstrap requires no assumption about distribution. }\end{array}$} \\
\hline
\end{tabular}




\section{c. Data:}

IPO data are gathered from HOSE and HNX, and from four companies on Upcom floor with auction data. Data gathering process is as follows:

First of all, names of companies listed on HOSE and HNX are collated. Up to July 2012, 698 shares have been listed on the two stock exchanges. Secondly, list of auctions conducted on the two exchanges is established. The list comprises 348 auctions.

Comparison of the two lists shows that only 108 companies out of 348 auctions are listed ones (52 on HOSE and 54 on HNX). With availability of four auctions of shares on Upcom market, the authors gather 110 auctions.

Data about such auctions are from announcements of auctions by stock exchanges. The first trading day is determined by consulting the listing table on websites of the two exchanges and price data publicized by Phú Toàn and Vietstock companies.

Basic information of IPO companies is collected from their prospectuses. IPO prospectuses of some companies of them could not be found and no information about their total assets before IPOs is gathered. Number of documented auctions is 108. Comparison of auction date with listing date shows that 39 auctions are carried out after the listing day, and some of them are second auctions. They are not IPO auctions and removed from the sample. The sample, therefore, comprises only 69 IPOs.

\section{ANALYSIS OF EVIDENCE OF UNDERPRICING OF VIETNAMESE IPOS \\ a. Evidence of Underpricing of IPOs in Vietnam:}

Figures 1 and 2 show that underpricing degrees in surveyed companies are very different; MAAR amounts to $361 \%$ in PV Drilling and falls to $-89 \%$ in Vinamilk. AR experiences a wider difference: it varies from $753 \%$ in PV Drilling to $-231 \%$ in ABT.

Of 60 IPOs in Vietnam, 49 have MAAR (AR) greater than zero. The underpricing expressed by MAAR is $49.09 \%$ with a standard deviation of $103.5 \%$. This high standard deviation implies that a high dispersion exists in underpricing of surveyed IPOs. Expressed in AR, underpricing reaches $30.01 \%$ with a high standard deviation of $134.5 \%$. Table 2 the average underpricing based on MAAR is statistically significant at $1 \%$ while significance for AR is $5 \%$. Thus, it could be concluded that there is evidence of underpricing of IPOs in Vietnam.

Difference in underpricing degrees in IPOs by financial firms and non-financial ones is also examined. Table 2 shows that underpricing by non-financial firms (with an average 
MAAR of $51.53 \%$ ) is greater than that of financial ones (with the average MAAR of $32.82 \%$ ) but this difference is not statistically significant.

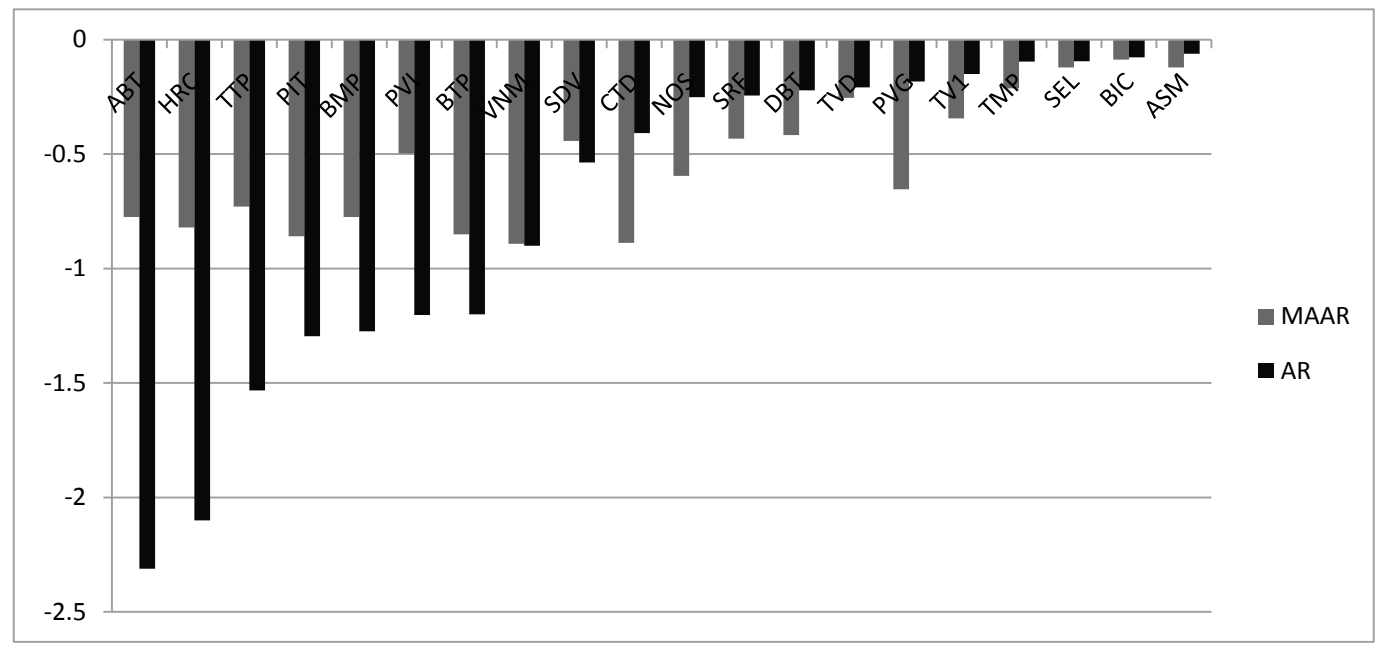

Figure 1: Companies with Negative First Day Market-Adjusted Returns

Source: Authors' calculations from data about auctions on HOSE, HNX and Upcom, and transaction data from Phú Toàn

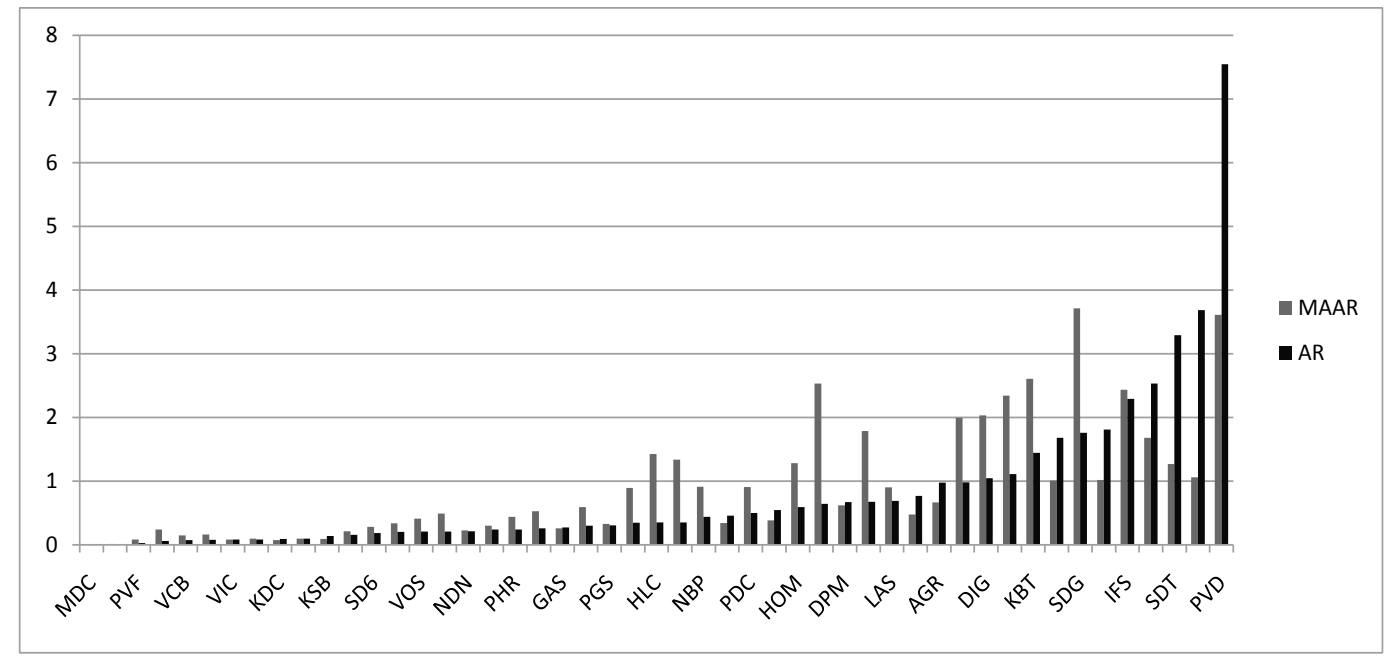

Figure 2: Companies with Positive First Day Market-Adjusted Returns

Source: Authors' calculations from data about auctions on HOSE, HNX and Upcom, and transaction data from Phú Toàn 
Regarding IPOs by financial firms, there are nine IPOs by banks and stock brokerage firms $(13.04 \%)$, but majority of them are launched by leading state-owned banks and corporations that control such industries as banking and insurance, including Bảo Việt Insurance Group, Bank for Foreign Trade of Vietnam, Bank for Investment and Development of Vietnam, and PetroVietnam Insurance Corporation.

Generally, underpricing by financial firms is lower than that in non-financial ones because IPOs in financial sector raise huge interest from investors who believe in potentials for high growth rates in this sector and possible improvement in competitiveness of financial firms with participation for private persons after an IPO. Business performance of the firms, however, fell short of expectations after an IPO. Moreover, first trading days of financial IPOs took place when the global financial crisis broke out with the result that prices of financial shares fell drastically in the first trading days in comparison with shares from nonfinancial firms.

Table 2: One-Sample t-Test for Underpricing

\begin{tabular}{lllllll}
\hline & Mean & \multicolumn{1}{c}{$\begin{array}{c}\text { Standard } \\
\text { deviation }\end{array}$} & t & p-value & $\begin{array}{c}\text { Standard } \\
\text { error }\end{array}$ & Obs. \\
\hline MAAR & 0.4908865 & 1.035140 & 3.9392 & 0.0002 & 0.1246162 & 69 \\
AR & 0.3801205 & 1.344833 & 2.3479 & 0.0218 & 0.1618988 & 69 \\
\hline
\end{tabular}

Table 3: Test for Underpricing by Financial and Non-Financial Firms

\begin{tabular}{lcccccc}
\hline & $\begin{array}{c}\text { IPO by } \\
\text { non-financial firms }\end{array}$ & $\begin{array}{c}\text { IPO by } \\
\text { financial firm }\end{array}$ & Difference & t & p-value & Obs. \\
\hline MAAR & 0.5153 & 0.3282 & 0.1871 & 0.5028 & 0.6167 & 60 \\
AR & 0.3845 & 0.3511 & 0.0334 & 0.0689 & 0.9453 & 9 \\
\hline
\end{tabular}

Source: Authors' calculations from data about auctions on HOSE, HNX and Upcom, and transaction data from Phú Toàn.

Table 4: Underpricing over Time

\begin{tabular}{lccc}
\hline \multicolumn{1}{r}{ Period } & $\mathbf{2 0 0 5 - 2 0 0 7}$ & $\mathbf{2 0 0 8 - 2 0 0 9}$ & $\mathbf{2 0 1 0 - 2 0 1 2}$ \\
\hline MAAR & 0.5173 & 0.3263 & 0.5300 \\
AR & 0.4016 & 0.3016 & 0.3326 \\
\hline
\end{tabular}

Source: Authors' calculations from data about auctions on HOSE, HNX and Upcom, and transaction data from Phú Toàn 
To see clearly changes in underpricing of IPOs over bull and bear markets, the authors calculate mean values of MAAR and AR over time. Table 4 shows that average MAARs of IPOs in 2005-2007 and 2010-2012 periods are not much different and greater than that of 2008-2009. The sample data show that there are 10 IPOs in the 2008-2009 period equaling $14.49 \%$ of surveyed IPOs. This figure shows a considerable decrease compared with the previous period. The authors also find that three out of 10 IPOs in this period suffer negative MAAR and no IPO gains a high MAAR while severely-underpriced IPOs are found in the 2005-2007 period.

Unlike most foreign markets where book building method is popular, all IPOs in Vietnam are carried out by separate auctions. As a result, the adjusted first day rate of return is based on the average awarded bid but in fact, each investor pay according to their own awarded bid. Investors offering the lowest bid may gain the adjusted first day return higher than the average. The authors, therefore, also report the adjusted first day return for investors who offer the lowest bid and get awarded. Winners offering the highest bid only gain a low rate of return. According to Vietnamese regulations on auction of shares included in Stipulation 115/QĐ-UBCK issued by State Securities Commission on Feb. 13, 2007, bidders are required to deposit $10 \%$ of value of share lots they want to buy at initial price. Some typical IPOs in the sample obtained their highest bids that were many times higher than the initial prices. For example, in the IPO by Thác Mo Hydropower Company, the highest bid was VND56 million while the initial price was only VND20,000. These figures were VND29.5 million and VND17,000 respectively in IPO by Bến Tre Pharmaceuticals Company, and VND11.7 million and VND10,100 in IPO by Biển Bắc Transportation Company, but most bidders who offered these highest bids reportedly gave up their deposits.

Some bidders can distort the real value by placing an order for a small lot of shares at a very high price but after the auction they refuse to buy the lot, and the highest price is only a false one. For this reason, the research does not examine adjusted rate of return for investors who offer maximum prices.

Table 5 shows that winning investors with the lowest bid gain a market-adjusted rate of return of $67 \%$ compared with the MAAR-based average of $49.09 \%$; or $49.93 \%$ compared with AR-based $38.01 \%$. These investors gain adjusted rates of return higher than the corresponding averages of $18.36 \%$ and $11.92 \%$ based respectively on MAAR and AR, and they are all statistically significant at $1 \%$. 
Table 5: Average First Day Return of the Lowest Bids

\begin{tabular}{lcccc}
\hline & Mean & Standard deviation & Standard error & Obs. \\
\hline MAARmin & 0.674563 & 1.187814 & 0.142996 & 69 \\
MAAR & 0.4908865 & 1.03514 & 0.1246162 & 69 \\
Difference & 0.1836765 & 0.4834554 & 0.582012 & \\
$\mathbf{t}$ & 3.1559 & & & \\
p-value & 0.0012 & & & \\
ARmin & 0.4993829 & 1.414594 & 0.1702971 & 69 \\
AR & 0.3801205 & 1.344833 & 0.1618988 & 69 \\
Difference & 0.1192624 & 0.28491 & 0.582012 & \\
T & 3.4771 & & & \\
p-value & 0.0004 & & & \\
\hline
\end{tabular}

Source: Authors' calculations from data about auctions on HOSE, HNX and Upcom, and transaction data from Phú Toàn

Can the highest awarded bid distort evidence of underpricing? The authors argue that the average adjusted return of IPOs is affected by unreasonably high bids because such bids can inflate the average bid. If this effect is eliminated, the underpricing degree may be even higher. Eliminating extremely high bids may consolidate evidence of underpricing.

However, in a market comprised mostly of small investors affected by herd behavior and psychology (Trần \& Hồ, 2007; and Trần, 2010), high bids only produce a small deviation. Such bids may have some relationships because investors may exchange information before and during the auction; and the price may be distorted because irrational investors offer higher prices on the first trading day, causing a prolonged underpricing pattern.

\section{b. Explanation of Underpricing of IPOs in Vietnam:}

Table 6 presents descriptions of factors to be considered during regression analysis. Average ratio of oversubscription in IPOs is 4.28 times. Although this ratio is rather high, the dispersion is wide. Listing time lag for IPO companies in Vietnam is long - 599 days on average. Average company age from establishment to IPO is 17.8 years, varying from two to 50 years. It is noteworthy that many companies have been under state ownership, operating under the centrally-planned mechanism and being saved from competition. And 
therefore, companies with high ages do not imply that they have better competitiveness and are familiar to the market and free from information asymmetry as their counterparts in developed markets.

Table 6: Data Description

\begin{tabular}{lcccccc}
\hline & Mean & Min. & Max. & $\begin{array}{c}\text { Standard } \\
\text { deviation }\end{array}$ & Skewness & Kurtosis \\
\hline AR & 0.3801 & -2.3115 & 7.5439 & 1.3448 & 2.3812 & 13.7214 \\
MAAR & 0.4909 & -0.8925 & 3.7132 & 1.0351 & 1.0988 & 4.1034 \\
Demand & 4.2874 & 0.0400 & 15.2981 & 3.6697 & 1.1601 & 3.6796 \\
Del (day) & 599.8 & 42 & 1,434 & 356 & 0.3980 & 2.4470 \\
Age (year) & 17.8406 & 2.0000 & 50.0000 & 12.9293 & 0.9447 & 3.0538 \\
Std & 0.0372 & 0.0198 & 0.0990 & 0.0155 & 2.4626 & 9.5929 \\
FSize & $7,230.48$ & 34.59 & $167,127.83$ & $28,555.98$ & 5.1833 & 29.0235 \\
(VND billion) & & & & & & \\
Stateown & 0.4855 & 0.0000 & 0.9989 & 0.2782 & -0.5084 & 2.2112 \\
MarRetun & 0.0378 & -0.3952 & 0.5945 & 0.2291 & 0.3811 & 2.4185 \\
Resprice & 57,014 & 10,000 & $1,400,000$ & 174176 & 6.9231 & 53.0327 \\
(VND) & & & & & & \\
\hline
\end{tabular}

Source: Authors' calculations from data about auctions, and prospectuses of IPO companies on HOSE, HNX and Upcom, and transaction data from Phú Toàn

Average size of company asset in the year right before IPO is VND7,230 billion, varying widely between VND34.59 billion and VND167,127.83 billion. Average proportion of state ownership found in the sample is $48.55 \%$. Average initial price in auctions is VND57,014 but difference between the highest and lowest initial prices is also very wide. Market cumulative rate of return in a 3-month period before the first trading day is 3.78\%.

Table 7 shows relationships between factors. It seems that very few relationships could be found between explanatory variables and MAAR and AR. Multicollinearity test shows that this phenomenon does not exist among variables (average VIF is equal to 1.35). 
Table 7: Correlations Between Factors

\begin{tabular}{|c|c|c|c|c|c|c|c|c|c|c|}
\hline & MAAR & $\mathrm{AR}$ & Demand & LnDel & LnAge & LnFSize & Std & Stateown & MarReturn & Inresprice \\
\hline MAAR & 1.0000 & & & & & & & & & \\
\hline \multirow[t]{2}{*}{ AR } & 0.7633 & 1.0000 & & & & & & & & \\
\hline & 0.0000 & & & & & & & & & \\
\hline \multirow[t]{2}{*}{ Demand } & -0.2242 & -0.1678 & 1.0000 & & & & & & & \\
\hline & 0.0640 & 0.1681 & & & & & & & & \\
\hline \multirow[t]{2}{*}{ LnDel } & -0.0071 & -0.0816 & 0.2033 & 1.0000 & & & & & & \\
\hline & 0.9537 & 0.5049 & 0.0938 & & & & & & & \\
\hline \multirow[t]{2}{*}{ LnAge } & 0.0520 & -0.0988 & 0.0216 & 0.1923 & 1.0000 & & & & & \\
\hline & 0.6713 & 0.4194 & 0.8600 & 0.1134 & & & & & & \\
\hline \multirow[t]{2}{*}{ LnFSize } & -0.0953 & -0.0221 & -0.1195 & -0.1668 & 0.2246 & 1.0000 & & & & \\
\hline & 0.4361 & 0.8568 & 0.3281 & 0.1707 & 0.0636 & & & & & \\
\hline \multirow[t]{2}{*}{ Std } & -0.0045 & -0.0091 & 0.2819 & 0.2927 & -0.1009 & -0.3362 & 1.0000 & & & \\
\hline & 0.9710 & 0.9408 & 0.0190 & 0.0147 & 0.4094 & 0.0047 & & & & \\
\hline \multirow[t]{2}{*}{ Stateown } & 0.0555 & 0.1244 & -0.1501 & 0.1221 & 0.0840 & 0.4485 & 0.0007 & 1.0000 & & \\
\hline & 0.6503 & 0.3087 & 0.2184 & 0.3178 & 0.4927 & 0.0001 & 0.9955 & & & \\
\hline \multirow[t]{2}{*}{ MarReturn } & 0.0043 & 0.1481 & 0.0215 & -0.0241 & 0.2022 & 0.2707 & -0.1167 & 0.2259 & 1.0000 & \\
\hline & 0.9718 & 0.2246 & 0.8607 & 0.8442 & 0.0956 & 0.0245 & 0.3395 & 0.0620 & & \\
\hline \multirow[t]{2}{*}{ Lnresprice } & -0.4612 & -0.4326 & -0.1230 & -0.3224 & -0.0418 & 0.1007 & -0.1783 & -0.3274 & 0.0429 & 1.0000 \\
\hline & 0.0001 & 0.0002 & 0.3140 & 0.0069 & 0.7331 & 0.4104 & 0.1427 & 0.0060 & 0.7265 & \\
\hline
\end{tabular}

Source: Authors' calculations from data about auctions, and prospectuses of IPO companies on HOSE, HNX and Upcom, and transaction data from Phú Toàn

Tables 8 and 9 present regression results for underpricing expressed in MAAR and AR along with explanatory variables by all three methods: OLS, OLS with heteroskedasticity adjusted (robust) and bootstrap. Only two factors that have negation correlations with MAAR (oversubscription and initial price) at a level of significance of $1 \%$. As for AR, in addition to the two aforementioned factors, factor "market condition" has a positive correlation at $10 \%$. 
Table 8: Regression Results - with MAAR

\begin{tabular}{lccccccc}
\hline & & \multicolumn{2}{c}{ OLS } & \multicolumn{2}{c}{ Robust } & \multicolumn{2}{c}{ Bootstrap } \\
\cline { 3 - 7 } & Coefficient & $\mathbf{t}$ & p-value & $\mathbf{t}$ & p-value & t & p-value \\
\hline Demand & -0.0866153 & -2.7000 & 0.0090 & -2.8800 & 0.0050 & -2.6600 & 0.0080 \\
LnDel & -0.1758478 & -1.1800 & 0.2440 & -1.1900 & 0.2400 & -1.1300 & 0.2570 \\
LnAge & 0.0906397 & 0.6500 & 0.5150 & 0.6300 & 0.5310 & 0.5900 & 0.5560 \\
Std & 1.097915 & 0.1400 & 0.8920 & 0.1900 & 0.8510 & 0.1400 & 0.8900 \\
LnFSize & -0.032162 & -0.3800 & 0.7030 & -0.4500 & 0.6560 & -0.4100 & 0.6820 \\
Stateown & -0.6163134 & -1.2100 & 0.2290 & -1.2200 & 0.2260 & -1.2000 & 0.2290 \\
MarReturn & 0.3224052 & 0.6400 & 0.5270 & 0.6400 & 0.5270 & 0.6000 & 0.5500 \\
Lnresprice & -0.6040954 & -4.8700 & 0.0000 & -4.2800 & 0.0000 & -3.8600 & 0.0000 \\
cons & 8.914719 & 3.3100 & 0.0020 & 2.9900 & 0.0040 & 2.6900 & 0.0070 \\
$\mathrm{R}^{2}$ & 0.342 & & & & & & \\
p-value & & & 0.0009 & & 0.003 & & 0.0121 \\
\hline
\end{tabular}

Table 9: Regression Results - with AR

\begin{tabular}{lccccccc}
\hline & & \multicolumn{2}{c}{ OLS } & \multicolumn{2}{c}{ Robust } & \multicolumn{2}{c}{ Bootstrap } \\
\cline { 3 - 8 } & Coefficient & $\mathbf{t}$ & p-value & $\mathbf{t}$ & p-value & $\mathbf{t}$ & p-value \\
\hline Demand & -0.0828104 & -1.9700 & 0.0540 & -2.6300 & 0.0110 & -2.2900 & 0.0220 \\
LnDel & -0.2970448 & -1.5100 & 0.1360 & -1.4700 & 0.1460 & -1.3600 & 0.1750 \\
LnAge & -0.1854277 & -1.0200 & 0.3120 & -0.7600 & 0.4490 & -0.7600 & 0.4470 \\
Std & 1.919618 & 0.1800 & 0.8570 & 0.2600 & 0.7970 & 0.2000 & 0.8440 \\
LnFSize & 0.0014312 & 0.0100 & 0.9900 & 0.0200 & 0.9880 & 0.0100 & 0.9890 \\
Stateown & -0.5551604 & -0.8300 & 0.4080 & -1.0200 & 0.3100 & -1.0100 & 0.3110 \\
MarReturn & 1.31733 & 1.9800 & 0.0520 & 1.6900 & 0.0970 & 1.6700 & 0.0960 \\
Lnresprice & -0.7546455 & -4.6400 & 0.0000 & -3.1000 & 0.0030 & -2.8600 & 0.0040 \\
cons & 10.74348 & 3.0400 & 0.0040 & 2.1500 & 0.0360 & 1.9200 & 0.0550 \\
$\mathrm{R}^{2}$ & 0.3286 & & & & & & \\
p-value & & & 0.0015 & & 0.0422 & & 0.0655 \\
\hline
\end{tabular}

Source: Authors' calculations from data about auctions, and prospectuses of IPO companies on HOSE, HNX and Upcom, and transaction data from Phú Toàn 
As mentioned above, with small samples, bootstrap-based regression inferences are more precise, and therefore, the following discussions focus on bootstrap results.

- Oversubscription (Demand): This factor has a negative relationship as expected and has a statistical significance at $1 \%$ with both measures MAAR and AR. This result matches findings by Biais \& Faugeron-Crouzet (1999) from a sample of 68 IPOs in France, and by Chi \& Padgett (2005) from 668 IPOs in China. Apparently, when demand is high, the number of shares demanded may exceed the supply by many times. Moreover, in auctioned IPOs (or issue by tender), where information is exchanged broadly or leaked easily, and more and more investors are interested in the auctions, bidders can offer higher prices, which reduces the underpricing.

- Initial price (LnResprice): This is an indicator of price levels offered by bidders. According to regulations on IPOs in Vietnam, a bid is legitimate when it is not lower than the initial price; and therefore, it becomes an important reference point when offering bid in IPOs in Vietnam. Regression results show that initial price at auction has a negative relationship as expected with underpricing and it is statistical significant at $1 \%$ with both MAAR and AR. Moreover, the significance level does not change in all regression calculations.

- Listing time lag (LnDel) of IPO shares has no correlation with underpricing. This factor bears a negative sign and is not statistically significant with both MAAR and AR. It is noteworthy that most IPOs in Vietnam include no plan for share listing and supply no information about the listing date on the auction day. The time lag reaches 599 days on average while this lag on foreign market is only some months or even some days after IPO. This implies that investors seem indifferent to this factor with the result that the time lag keeps getting longer and issuers keep failing to make plan for listing.

- Underpricing has no relationship with company age (LnAge) because p-value is high. Sign of this regression coefficient even changes when MAAR and AR are employed. Regarding expectations, investors usually know a company with a high age better than a younger one, and underpricing of IPO by a long-standing company may be lower. This argument, however, is not appropriate to IPOs in Vietnam. Most IPO companies in Vietnam have a long history, up to 50 years for the oldest, and the average age of surveyed companies is 17.8 years. Most of them, however, are state-owned companies that operation for years under the old mechanism where competition did not exist; and their long history does not reflect their strength and maturity. Moreover, high information asymmetry in the public sector does not ensure good knowledge of their operations for investors as theoretically expected.

- Regarding expectations, shares involving high degrees of risk leads to high uncertainty about price, and accordingly high underpricing. The results presented in Tables 8 and 9 show 
that underpricing has no relationship with fluctuations in rate of return on secondary market (MarReturn) although the corresponding coefficient bears a positive sign.

Regarding the size of company (LnFSize), the results are contrary to expectations: underpricing has no relationship with the size of company in the year before auction. Moreover, the signs of coefficients changes according to MAAR and AR. The authors see the difference between IPOs in Vietnam and foreign ones is when state-owned companies are large and strict regulations on information disclosure are not stringent, then information asymmetry does not reciprocal to the size as theoretically expected.

Proportion of Vietnamese state ownership (Stateown) has no relationship with underpricing while IPOs in China show a significantly negative correlation (Chi \& Padgett, 2005). In our opinion, the Vietnamese government usually withdraws its capital gradually in order to prevent loss, and the argument that underpricing is used for attracting individual investors is unreasonable. And unlike Chinese IPOs, it is investors in Vietnamese IPOs who determine prices of IPO shares by offering bids and the government can hardly intervene into auctions while Chinese government has the right to set prices.

- Market cumulative return in a 3-month period before the first trading day (MarReturn) has a positive and weak relationship with underpricing. This factor is statistically significant at $10 \%$ when underpricing is expressed by AR, and is not significant when MAAR is used for measuring the underpricing.

\section{CONCLUSION}

This research finds evidence of underpricing in IPOs at $38 \%$ and $49.09 \%$ on average. This underpricing degree is low in comparison with Chinese market; but it is much higher than that in developed markets.

Rate of return gained by investors who offer the lowest bids is $11.9 \%$ and $18.36 \%$ higher than the rate gained by investors who buy shares at the average bid; and this different is statistically significant.

Two factors that have consistent effects on underpricing in Vietnam are oversubscription and initial price. They also have direct relationships with each auction. Market condition only produces a weak effect while some other factors, such as company age, listing time lag, fluctuations in rate of return when shares are listed, company size before auctions, and state ownership after auction have no correlations with two measures of underpricing. These results are different from findings by previous researches worldwide. 


\section{IMPLICATIONS}

\section{a. Strategy for Investing in IPO Shares:}

The fact that oversubscription and initial price have negative correlations with underpricing implies that participation in auctions that are expected to have low oversubscription and initial price may produce outstanding results. To clarify this implication, the authors make a list of shares that enjoy low oversubscription and initial price (List L) and a list of shares that suffer high oversubscription and initial price (List $\mathrm{H}$ ) and calculate rate of return of the two lists. MAAR of the List $\mathrm{L}$ amounts to $90 \%$ compared with $-21 \%$ for the List $\mathrm{H}$. This result shows that investment in shares with low oversubscription and initial price is promising. This finding, therefore, is worth considering when investors take part in auctioned IPOs in Vietnam.

\section{b. Policy Recommendations:}

Offering very high bids and then giving up deposit are common in IPOs conducted according to regulations on auctions in Vietnam. This practice may distort IPO price. It is necessary to introduce measures, such as increasing required deposit, to prevent all practices for profiteering purposes.

Book building method may be introduced as a substitute for auctioning method in order to gain benefits from this internationally-acclaimed method, such as preventing extremely high bids that may distort issue prices, and enhancing sense of responsibility for financial disclosure among issuers, etc.

The research finds that listing time lag of IPOs in Vietnam is long and most companies have no plan for listing, which may produce liquidity barriers and risks for investors and make it difficult for companies to raise capital in the next issues. It is necessary to facilitate afterIPO listing by introducing regulations on the maximum interval of time between IPO and listing and simplifying procedures for listing to encourage companies to reduce this interval.

At present, only companies that conduct IPOs on stock exchange publicize results of IPOs while companies that have their IPOs carried out by stock brokerage firms fail to do so, which makes it difficult for researchers of IPOs and hinders investors from evaluating the shares after IPO because of the lack of information. Authorities, therefore, should introduce new regulations on supply of information about IPO results, and on information transparency for transactions on unofficial markets during the interval between IPO and listing dates 


\section{References}

Adjasi, C. K. D., K. A. Osei \& E. U. Fiawoyife (2011), "Explaining Underpricing of IPOs in Frontier Markets: Evidence from the Nigeria Stock Exchange", Research in International Business and Finance, 25(3), 255-265.

Ayayi, A. G. (2011), "Underpricing and Long-term Performance of Auctioned IPOs: The Case of Vietnam”, International Research Journal of Finance and Economics, 61.

Biais, B., \& A.M. Faugeron-Crouzet (2000), IPO Auctions: English, Dutch, ... French and Internet, Institut d'Économie Industrielle (IDEI), Toulouse.

Boudriga, A., S. Ben Slama \& N. Boulila (2009), What Determines IPO Underpricing? Evidence from a Frontier Market, University Library of Munich, Germany.

Bradley, D. J., J. S. Gonas, M. J. Highfield, \& K. D. Roskelley. (2009), “An Examination of IPO Secondary Market Returns", Journal of Corporate Finance 15(3), 316-330.

Chambers, D. \& E. Dimson (2009), "IPO Underpricing over the Very Long Run”, The Journal of Finance, 64(3), 1407-1443.

Chi, J., \& C. Padgett (2005), "The Performance and Long-run Characteristics of the Chinese IPO Market", Pacific Economic Review, 10(4), 451-469.

Ibbotson, R. G., J. L. Sindelar \& J. R. Ritter (1988), “Initial Public Offerings”, Journal of Applied Corporate Finance, 1(2), 37-45.

Kerins, F., K. Kutsuna \& R. Smith (2007), "Why are IPOs Underpriced? Evidence from Japan's Hybrid Auction-Method Offerings", Journal of Financial Economics, 85(3), 637-666.

Ritter, J. R., \& I. Welch (2002), "A Review of IPO Activity, Pricing, and Allocations”, The Journal of Finance, 57(4), 1795-1828.

Samarakoon, L. P. (2010), "The Short-Run Underpricing of Initial Public Offerings in the Sri Lankan Stock Market”, Journal of Multinational Financial Management, 20(4-5), 197-213.

Sohail, K. M., \& Raheman, A. (2009), "Determinants of Underpricing of IPOs Regarding Financial \& Non-Financial Firms in Pakistan”, European Journal of Economic, Finance \& Administrative Sciences.

Tian, L. (2011), "Regulatory Underpricing: Determinants of Chinese Extreme IPO Returns", Journal of Empirical Finance, 18(1), 78-90.

Trần Ngọc Thơ \& Hồ Quốc Tuấn (2007), "Ứng dụng tài chính hành vi vào phân tích thực tiễn”, Phát triển kinh tế, 201, 2-5.

Trần Thị Hải Lý (2010) "Herd Behavior in Vietnamese Stock Market: Causes and Some Solutions", Economic Development Review, 186. 